\title{
Distribution and habitat use of Neotropical migrant landbirds in the Amazon basin and Andes
}

\author{
S. K. ROBINSON, J. W. FITZPATRICK and J. TERBORGH
}

\begin{abstract}
Summary
We documented the geographical distributions and habitat selection of Neotropical migrants in South America along a successional gradient in the lowlands of Amazonian Peru, and along elevational gradients in the Andes of south-eastern Peru and of eastern and western Ecuador. Most of the 30 species of northern migrants that regularly winter in South America appear to be concentrated in the western edge of the Amazon basin and on the lower slopes $(<2,000 \mathrm{~m})$ of the Andes. Migrants in a lowland site were documented more often in early successional habitats than in primary forest, and no species were confined to mature forest habitats. The number of species and relative abundance of migrants in primary forest, however, increased with elevation up to about $1,200 \mathrm{~m}$ and decreased above that elevation. Several species (Contopus borealis, Dendroica cerulea and Wilsonia canadensis) were largely confined to primary forest in the 1,00o2,000 $\mathrm{m}$ elevational zones in both Peru and Ecuador. Migrants on the western slope of the Ecuadorean Andes included several species that primarily winter further north. In general, the species richness of migrants and residents was inversely correlated, both on a biogeographical and a local scale. Migratory birds are most likely to be adversely affected by deforestation of the lower slopes of the Andes, which is proceeding at a rapid pace. The impact of human alterations of Amazonian forests will be greater on resident than on migratory birds. The loss of mid-successional lowland forests, however, might have a negative effect on several species.
\end{abstract}

\section{Introduction}

In the rapidly growing literature on the ecology and conservation of Neotropical migrant landbirds (e.g. Keast and Morton 1980, Terborgh 1989, Hagan and Johnston 1992, Finch and Stangel 1993), species that winter in South America have received comparatively little attention (Stotz et al. 1992). Of the 30 species of Neotropical migrant landbirds that winter regularly in Amazonian South America (Fitzpatrick 1980, Robinson et al. 1988, Stotz et al. 1992), none has been studied in detail, even though some are of great conservation concern (e.g. Cerulean Warbler Dendroica cerulea: Robbins et al. 1992b). Robinson et al. (1988) noted that Neotropical migrants were mostly found in early successional habitats in the Amazonian lowlands, but were commonly found in primary forest in the eastern Andes (see also Robbins et al. 1992b). These results are in general agreement with other studies showing low diversity and abundance of Neotropical migrants in primary lowland forest in Amazonia (e.g. Pearson 1980, 
Bierregaard 1990, Terborgh et al. 1990, Stotz et al. 1992, J.W.F. unpubl. data). Data from other studies of Andean forests are scarce but generally show that migrants use both primary and secondary forests (e.g. Chipley 1976, Terborgh 1989).

The purpose of this paper is to expand on the preliminary analysis of Robinson et al. (1988) by: (1) presenting data on the wintering distributions of Neotropical migrants in South America; (2) describing geographical replacements among closely related species; and (3) quantifying the habitat use of migrants along lowland successional gradients and elevational gradients in the Andes of Peru and Ecuador. We confirm that migrants concentrate in early and mid-successional habitats in the Amazonian lowlands, but occupy both primary and secondary forests in the middle elevations of the Andes. We then compare these results with overall patterns of species richness in these communities and with the much more extensive data from Central America (e.g. Lynch 1989, 1992, Greenberg 1992, Petit et al. 1992, Rappole et al. 1992, Robbins et al. 1992a).

\section{Study area and methods}

\section{Geographical distributions}

Wintering distributions for species reported here were mapped from published checklists, recent unpublished data from various fieldworkers, and unpublished records from specimens housed at the Field Museum of Natural History and the Louisiana State University Museum of Natural Science.

Amazonian lowlands. Habitat use of migrants was quantified in the vicinity of the Cocha Cashu Biological Station $\left(11^{\circ} 55^{\prime} \mathrm{S} 77^{\circ} 18^{\prime} \mathrm{W}\right)$ on the Manu River about $90 \mathrm{~km}$ upriver from the mouth. This area is in the Manu National Park, department of Madre de Dios, Peru. The bird community of this site has been described in detail in Terborgh et al. (1984, 1990), Terborgh (1985), Robinson et al. (1990), and Robinson and Terborgh (1990). The vegetation of this community has also been described in detail in Foster et al. (1986) and Terborgh and Petren (1991). The successional dynamics of rivers in this region create a complex mosaic of successional and backwater habitats (Salo et al. 1986), which contributes greatly to the high species richness of this area (Parker 1982, Remsen and Parker 1983, Terborgh et al. 1984, Terborgh 1985, Robinson et al. 1990).

We quantified the habitat use of migrants in the following successional stages from Terborgh's (1985) classification. (1) Beaches are exposed along the Manu River during the dry season (June-October). (2) Tessaria, a composite tree, and cane (Gynerium) dominate the earliest successional stage on the insides of meander loops. (3) Mid-successional forests constitute a diverse array of successional stages of increasing tree species richness and structural complexity with age (Terborgh and Petren 1991). (4) Mature floodplain forest only forms in areas that escape being recycled by the meandering rivers for a very long time (probably 300 years or longer: Terborgh and Petren 1991). This forest is extremely diverse and structurally complex, and has been censused intensively (Terborgh et al. 1990). (5) Terra firme or upland forest is above the level of the 
floodplain and consists of a heterogeneous mixture of mature forest, bamboo patches, and steep ravines. Terborgh and Petren (1991) estimate that terra firme forest covers roughly $70 \%$ of the western Amazon basin. (6) Oxbow lakes form when a meander loop of the Manu River becomes pinched off from the rest of the river. Cocha Cashu, the oxbow lake we studied, has a marshy border with shrubs invading the drier sections of the marsh and figs growing along the edge (Bolster and Robinson 1990).

Peruzian Andes. We worked at three primary forest sites in the upper tropical zone of the Andean foothills $(600-1,400 \mathrm{~m}$ ) and one at $2,700 \mathrm{~m}$ in the upper subtropical zone. The upper tropical zone sites had a maximum canopy height of $35 \mathrm{~m}$, and the upper subtropical site consisted of primary elfin cloud-forest. All sites were located in the Cosñipata Valley in the departments of Cusco and Madre de Dios, south-eastern Peru (c. $11^{\circ} \mathrm{S} 78^{\circ} \mathrm{W}$ ). Data from 400-1,400 $\mathrm{m}$ were gathered in the general vicinity of the towns of Pilcopata, Atalaya and Shintuya. Camps and study sites in these locations in the foothills were amidst undisturbed, humid pre-montane rainforest.

Ecuadorean Andes. Work was conducted by J.T. in February 1986 on both the eastern and western slopes of the Andes in the Parque Nacional Sangay $(1,400 \mathrm{~m}$, east slope), Puyo-Tena road (600 m), Hacienda San Vincente near the town of Mindo (1,500 m, west slope), Tinalandia ( $760 \mathrm{~m}$, west slope), the Río Palenque (225 m, west slope), Río Coca (380 m, east slope), Salto de Coca $(1,330 \mathrm{~m}$, east slope), and Volcán Reventador $(1,600 \mathrm{~m})$. Habitats censused include primary and secondary forests (road edges and overgrown pastures) at all sites.

\section{Methods}

Two census methods were used to quantify habitat use of Neotropical migrants. (1) Visual censuses were conducted in specific habitats. Observers walked through habitats counting every bird observed, a method used by Pearson (1980) and Robinson et al. (1988). The percentage of Neotropical migrants in each sample (a minimum of 50 birds per sample) and the number of each species of migrant were calculated. Because we already reported data from the percentages of all migrants in each habitat at our Peruvian sites (Robinson et al. 1988), our emphasis in this paper will be on the distributions of each species. Results from the Ecuadorean transects, however, have not been published elsewhere. Visual counts tend to be biased towards canopy-dwelling species (Robinson et al. 1988), unlike mist-net samples. We did not record singing birds, to avoid biasing our detections in favour of territorial resident species. We made no attempt to quantify absolute abundance or population densities of migrants in any habitat. For visual censuses, we only used counts conducted from November through February in each habitat.

Additional flock counts were made in transects in the eastern Andes. Because these results have already been published in Robbins et al. (1992b), however, we mention them only briefly. 
Mist-net censuses were conducted in November-February in habitats at various successional stages of the lowlands of the Manu National Park, along the elevational gradient in the Peruvian Andes and at $1,500 \mathrm{~m}$ in the western Andes of Ecuador. Mist-nets (12-m, with 36-mm mesh) were strung end to end in lines of 10-40 nets and opened from dawn to dusk on 2-4 consecutive days. We calculated the numbers of individuals of each species captured and the percentages of migrants in each sample. Because mist-net samples are strongly affected by vertical habitat structure and interspecific differences in movement patterns, we use these data only as general indices of the presence of migrants in particular habitats and elevational stages. We assume, however, that very large (five-fold) differences in proportional captures in mist-nets are correlated with differences in abundance. We used only data from net lines from November through February to maximize the numbers of migrants in samples. For the Manu National Park, we combined data from all years, 1973-1985, in our samples from each successional stage. For netting results in the Peruvian Andes, an effort was made to capture a minimum of 300 individual birds per sample. In the lowlands, each sample was smaller, but cumulative samples from all years contained up to 1,000 individuals sampled in some habitats.

\section{Results}

\section{Geographical distributions}

Thirty landbird species regularly winter in significant numbers in the Amazon and central Andes south of Colombia (Appendix 1). Two other species, Empidonax virescens and Vermivora chrysoptera, were recorded in our Ecuadorean sample (see below), but mostly winter farther north. The 30 species fall mostly into two broad ecological categories: foliage-gleaning insectivores (19 species) and aerial insectivores (nine species; Appendix 1). Many of the foliage gleaners and at least one aerial insectivore (Tyrannus tyrannus) also consume significant amounts of fruit on the wintering grounds (Morton 1971, Fitzpatrick 1980). Foliage-gleaning insectivores are predominantly species that breed in eastern North America and migrate along the Caribbean coast of Mexico and Central America, whereas the aerial foragers show more widespread North American distributions (Figure 1).

Besides the Osprey Pandion haliaetus, an aquatic feeder, only a single raptor (Buteo platypterus) commonly winters in the area, although two others $(B$. swainsoni and Ictinia mississippiensis) pass through along the Andean foothills in transit to the south (Davis 1989, Terborgh et al. 1989). Winter distributions of foliage gleaners and aerial foragers show a distinct tendency to be concentrated toward the western edge of the Amazon basin and eastern Andes (Figure 1). Even those few species that occur across much of the Amazon basin are considerably more common in the west and north. The central and eastern Amazonian lowlands are almost devoid of migrants from North America.

\section{Geographical segregation}

Fitzpatrick (1980) showed that closely related migrant tyrannid flycatchers are distributed in winter as mosaics of largely allopatric or parapatric ranges across 


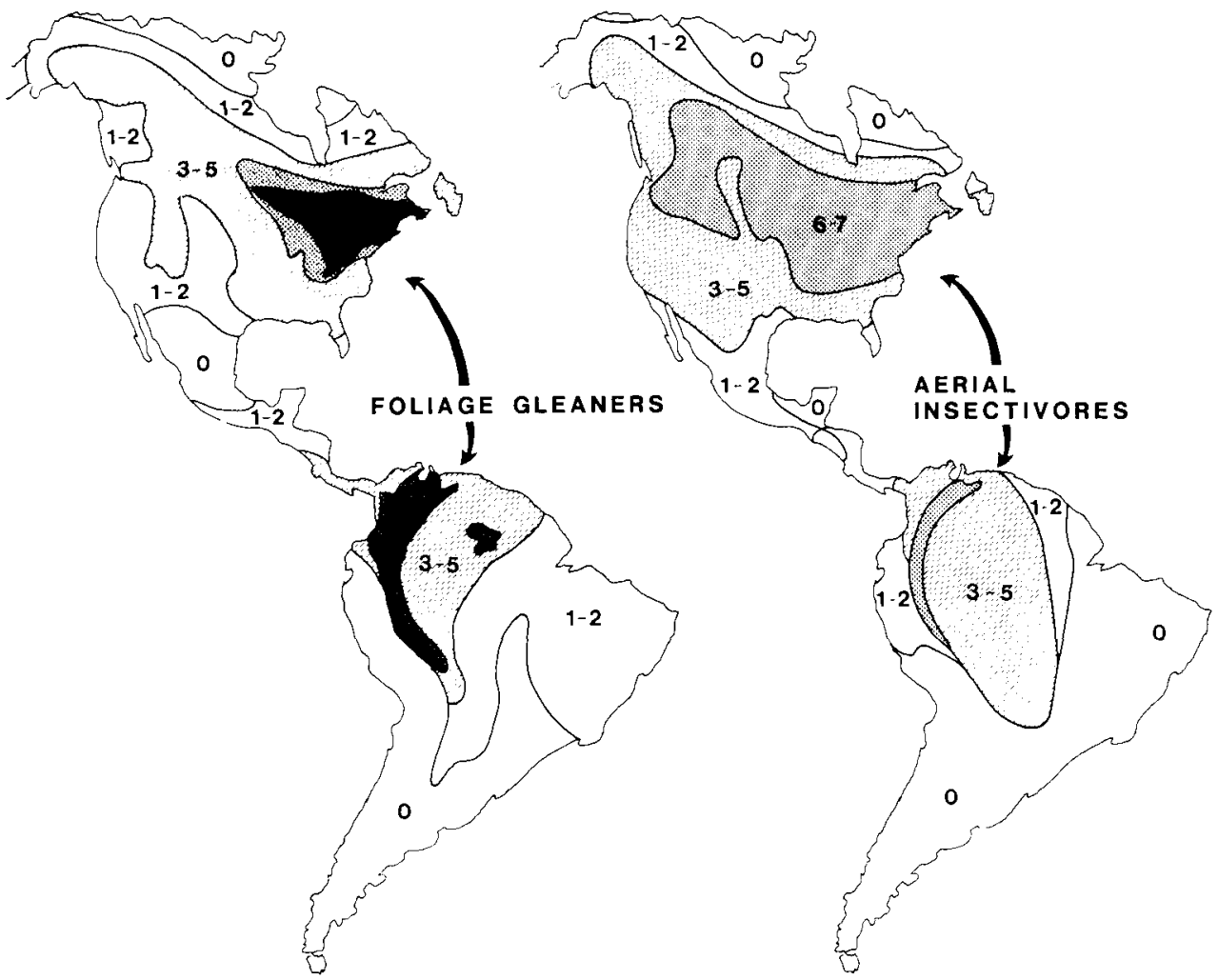

Figure 1. Breeding and wintering distributions of bird species whose predominant winter distributions fall in the Amazon drainage. Isopleths and shading depict geographic patterns of species richness for foliage gleaners ( 18 species) and aerial-insect feeders ( 9 species). Black, 11-13 species; dark stippling, 8-10 species; figures for remaining shades are shown on maps.

the Neotropics. Additional groups of foliage-gleaning species that include Amazonian winterers show this tendency as well, especially thrushes (Catharus spp.) and several groups of wood warblers (Oporornis spp., Wilsonia spp., Dendroica spp.) (Chipley 1980). The Amazon basin generally harbours the southernmost species in each of several genera or species groups, such that any one locality typically contains only one species from each group (Fitzpatrick 1980).

Geographical replacement among closely related migrants on their wintering grounds is more conspicuous among the foliage-gleaning species than among the aerial foragers. Among the species foraging on aerial insects, only two species pairs show substantial geographical segregation. Segregation among Tyrannus kingbirds was mapped in Fitzpatrick (1980). In addition, Western and Eastern Wood-pewees Contopus sordidulus and $C$. virens both winter in the forested Andes. Reliable records of $C$. sordidulus are scarce, especially south of Colombia; all records are from elevations above $1,200 \mathrm{~m}$. Records of $C$. virens are widespread south to Peru and Bolivia, and indicate a substantial lowland population in the western Amazon basin (see below). Contopus borealis overlaps 
Table 1. Number of Neotropical migrants netted and observed in the major habitats present in the vicinity of the Cocha Cashu Biological Station. All counts made from 1 to 30 November $1984-1986$

\begin{tabular}{|c|c|c|c|c|c|c|c|c|}
\hline \multirow[t]{2}{*}{ Species } & \multicolumn{2}{|c|}{ Tessaria/Cane } & \multicolumn{2}{|c|}{ Mid-successional forest } & \multicolumn{2}{|c|}{ Mature floodplain } & \multicolumn{2}{|c|}{ Terra firme } \\
\hline & Net & Visual & Net & Visual & Net & Visual & Net & Visual \\
\hline $\begin{array}{l}\text { Coccyzus } \\
\text { erythropthalmus }\end{array}$ & 0 & + & O & 0 & o & 0 & 0 & 0 \\
\hline C. americanus & 0 & + & o & + & o & + & 0 & 0 \\
\hline Contopus borealis & 0 & 0 & o & + & 0 & o & o & 0 \\
\hline C. virens & 1. & 0 & 1 & 11 & 0 & 2 & 0 & 1 \\
\hline Empidonax alnorum & 24 & 1 & 2 & 0 & o & $o$ & 0 & 0 \\
\hline $\begin{array}{l}\text { Myiodynastes } \\
\text { luteiventris }\end{array}$ & o & 2 & o & 9 & o & o & o & o \\
\hline Tyrannus tyrannus ${ }^{a}$ & I & $6(44)$ & o & $1(17)$ & o & o & o & o \\
\hline Catharus ustulatus & 2 & 3 & 1 & 4 & 8 & + & 4 & 1 \\
\hline Piranga rubra & 0 & 0 & $o$ & + & o & + & 0 & 0 \\
\hline P. olizacea & 0 & 0 & o & + & 0 & + & 0 & + \\
\hline Oporomis agilis & 2 & 0 & o & 0 & o & 0 & 0 & 0 \\
\hline Vireo olizaceus & 0 & o & o & $I$ & $o$ & 0 & 0 & 0 \\
\hline$V$. flazoviridis & 1 & o & o & 4 & 0 & 0 & 0 & 1 \\
\hline Dolichomyx oryzizora & 1 & 3 & o & o & o & o & 0 & o \\
\hline Total migrants & 32 & 15 & 4 & 30 & 8 & 2 & 4 & 4 \\
\hline Total sample & 182 & 121 & 123 & 342 & 669 & 312 & 364 & 322 \\
\hline \%. Migrants & 17.6 & 12.4 & $3 \cdot 3$ & 8.9 & 1.2 & 0.6 & 1.1 & 1.2 \\
\hline $\begin{array}{l}\text { Captures/ } \\
100 \text { net-days }\end{array}$ & \multicolumn{2}{|c|}{$133 \cdot 3$} & \multicolumn{2}{|c|}{6.7} & \multicolumn{2}{|c|}{1.4} & \multicolumn{2}{|c|}{1.4} \\
\hline
\end{tabular}

A "+" sign indicates that the bird has been observed in this habitat, but not during the sample.

"This species occurs in flocks; the number given is the number of flocks observed, the number in parentheses refers to the number of birds present in flocks.

C. virens throughout its wintering and breeding ranges, but tends to be found at higher elevations (see below).

Geographical and elevational segregation also occurs among the three southernmost-wintering species of Dendroica warblers. All three species ( $D$. fusca, D. cerulea, and D. striata) winter in mixed-species flocks in the forest canopy or subcanopy of South America (Robbins et al. 1992b). Of 21 migratory species in this large North American genus, only $D$. striata regularly occurs in the forests of the lowland Amazon, predominantly north of the Amazon River (Pearson 1980). Along the Andean foothills, at elevations between 650 and $1,150 \mathrm{~m}$, only $D$. cerulea is encountered. Above $1,200 \mathrm{~m} \mathrm{D}$. cerulea is abruptly replaced by $D$. fusca, which occupies cloud-forests of middle and upper elevations nearly to 3,000 m (see Robbins et al. 1992b).

\section{Habitat preferences in the lowlands}

As described elsewhere (Robinson et al. 1988), both northern and austral migrants (as well as intratropical migrants) show a pronounced preference for open, brushy, and early successional habitats rather than tall, mature forest (Table 1; see also Bierregaard 1990 for data from Manaus, Brazil). Because species richness is higher in mature forest and lower in successional vegetation 


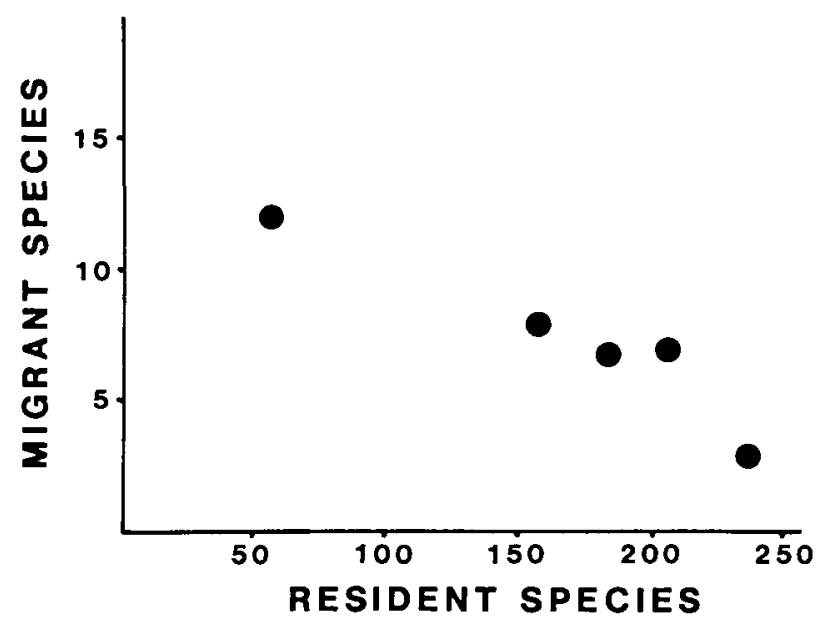

Figure 2. Species richness measures of migrant versus resident bird communities in south-eastern Peru, based on censuses of five tropical habitats conducted from October to December.

(Terborgh 1985, Terborgh et al. 1990), there is an inverse correlation between migrant and resident species richness (Figure 2). Among Neotropical migrants, only Contopus virens (large forest treefalls and bamboo patches), Catharus ustulatus, Vireo flavoviridis and Piranga olivacea were regularly observed or captured inside mature forest (Table 1). The capture rate of migrants in the earliest successional stages (Tessaria and cane) was nearly two orders of magnitude higher than in mature floodplain and terra firme forest, which together cover most of western Amazonia (Terborgh and Petren 1991). Mist-net samples, however, may be biased toward detecting migrants in early successional habitats because they sample the entire community in low, shrubby habitats whereas they only sample understorey birds in mature forest (Robinson and Terborgh 1990). For this reason, differences in capture rates should be treated with caution. Lake-margin samples (Robinson et al. 1988) also show high populations of Myiodynastes luteiventris and Tyrannus tyrannus, which forage mostly in lauraceous trees (Fitzpatrick 1980, S.K.R. unpubl. data). Four of our six lowland records of Contopus borealis were from the lake margin.

Several species were only recorded in the earliest successional stages (Table 1). Dolichonyx oryzivora was found only in marshes and in beach grasses. Empidonax alnorum was abundant in Tessaria and appeared to be territorial; individuals sang, occasionally chased each other, and at least two banded individuals were still present at their site of capture two weeks later (S.K.R. unpubl. data). Tyrannus tyrannus was often the most abundant bird during its southward migration. On 22 October 1982, 5,200 were counted passing over and foraging along the edge of Cocha Cashu (S.K.R. pers. obs.). By December, however, only a few small flocks (less than 50 individuals per flock) remained in the Cocha Cashu area. 


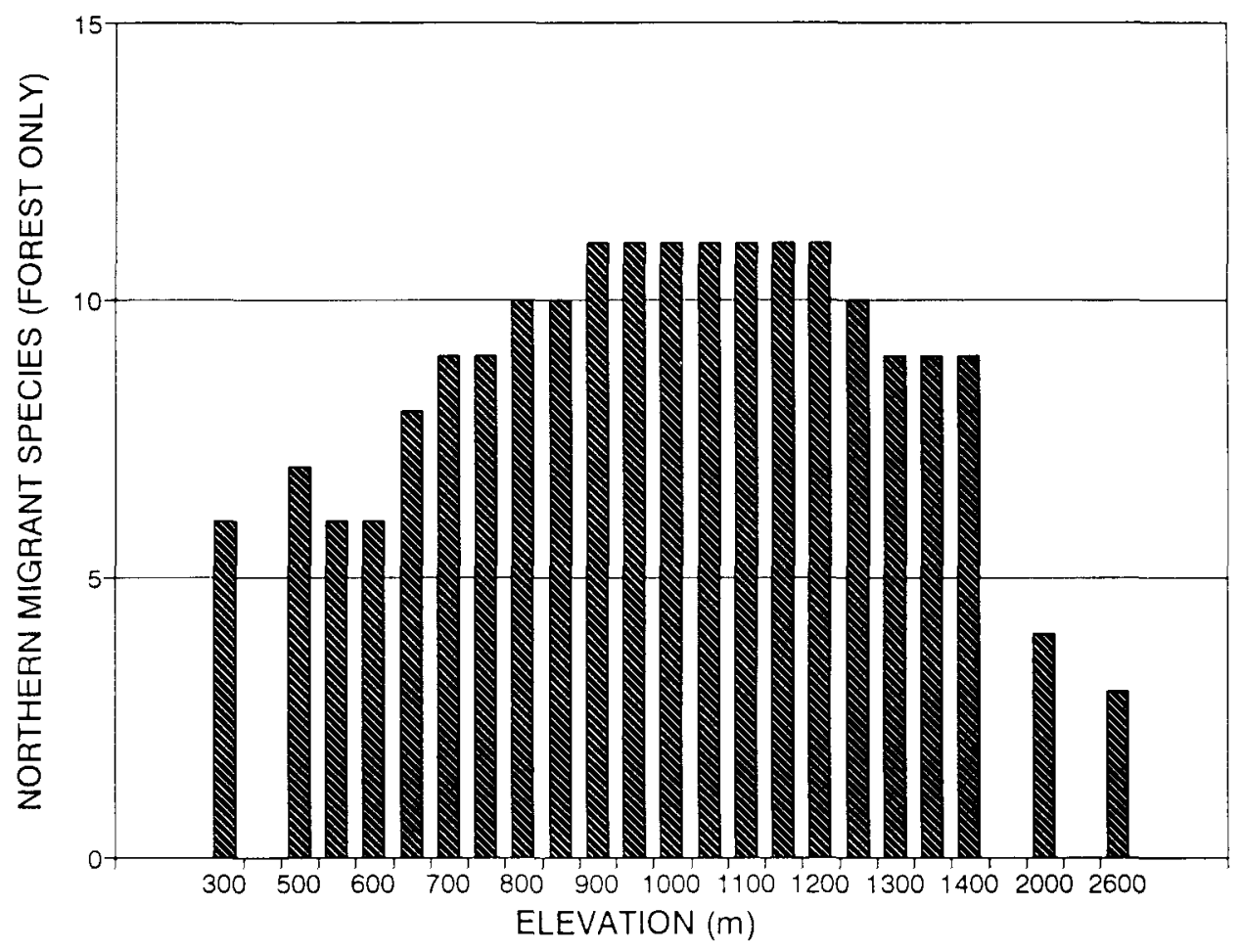

Figure 3. Numbers of migrant species observed in forest habitats along an elevational gradient in south-eastern Peru.

Migrants in the eastern Andean foothills

In the foothills and middle elevations of the forested eastern Andes, migrants made more extensive use of forest. Species richness of migrants in forest increased with elevation up to about 1,200 $\mathrm{m}$ (Figure 3), but decreased at higher elevations (see also Robinson et al. 1988, Robbins et al. 1992b). The proportion of Catharus ustulatus in mist-net samples in the Andes increased with elevation. Below $600 \mathrm{~m}$, less than $5 \%$ of the captures were C. ustulatus, whereas samples between 700 and $1,500 \mathrm{~m}$ contained $10-22 \%$ C. ustulatus (J.W.F. unpubl. data). If $C$. ustulatus forages higher in the canopy in the taller lowland forests, however, these estimates of abundance could be biased in favour of the lower canopy of higher-elevation forests.

\section{Use of flocks in south-eastern Peru}

Observations of mixed-species flocks reported in Robbins et al. (1992b) showed that most foliage-gleaning migrants in South America join the flocks described by Munn and Terborgh (1979), Munn (1985) and Powell (1985). In south-eastern Peru, the number and species richness of northern migrants inhabiting flocks increases with elevation (Figure 4) and was inversely correlated with the species 


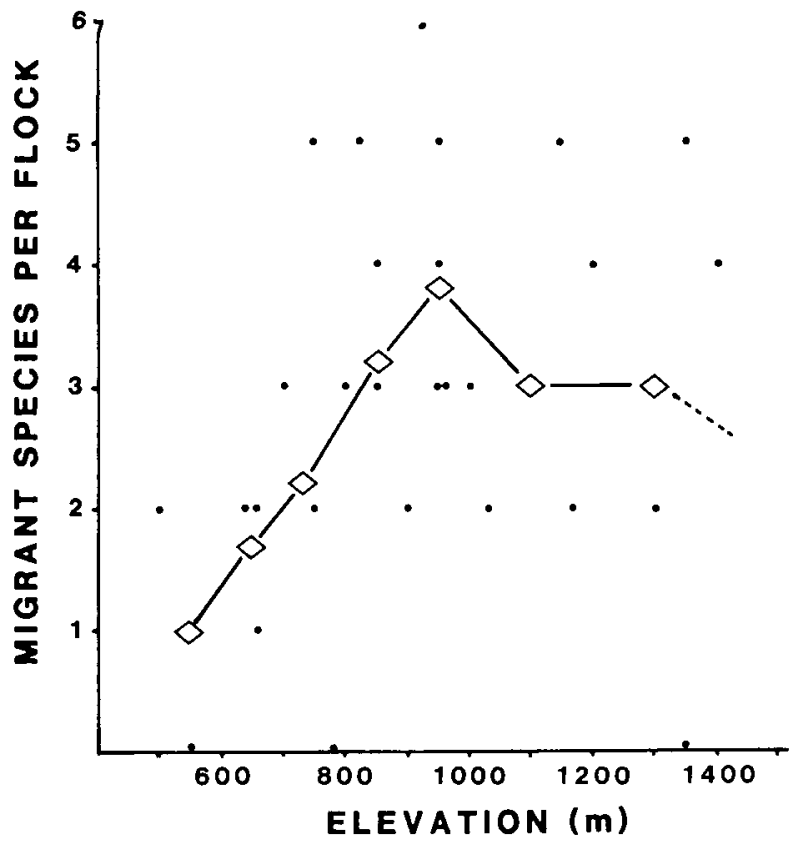

Figure 4 . Species richness of northern migrants in 28 canopy flocks plotted against elevation. Mean values are shown (with open diamonds) for elevational intervals centred at $550,650,750,850,950,1,100$, and $1,300 \mathrm{~m}$. Flocks above $1,400 \mathrm{~m}$ were not censused quantitatively, but are known to contain fewer migrants.

richness of the total forest bird community (Figure 5). At 2,600 m, only two migrant species were observed in flocks, one of which (Pheucticus ludovicianus) was not recorded at lower elevations. The number of migrants in flocks reached its peak between 800 and $1,000 \mathrm{~m}$. The most abundant warbler in flocks was Wilsonia canadensis, which occurred in virtually every subcanopy and canopy flock from 600 to $1,400 \mathrm{~m}$, occasionally in pairs (Robbins et al. 1992b). Wilsonita forages lower in the canopy than Dendroica cerulea or D. fusca. These three warblers have never been recorded in the lowlands around Cocha Cashu. Interestingly, we never observed $D$. fusca and $D$. cerulea in the same flocks (Robbins et al. 1992b). The geographical, ecological and elevational segregation among the five species of migrant warblers in south-eastern Peru is shown schematically in Figure 6. The Blackpoll Warbler D. striata occurs mainly north of the Amazon.

In addition to the warblers, four other northern migrants were observed in flocks along the elevational gradient. Vireo olivaceus was found in 25 of 28 flocks between 500 and $1,400 \mathrm{~m}$ (total of 61 individuals), with no discernible decrease in abundance at higher elevations. Of the two tanagers, Piranga olivacen was more abundant (present in 16 of 28 flocks, 35 individuals) than P. rubra (6 of 28 flocks; seven individuals). Both species were absent at $2,600 \mathrm{~m}$. Coccyzus americanus was recorded in two flocks at $500 \mathrm{~m}$ and $920 \mathrm{~m}$, but was observed at all 10 sites between 300 and $900 \mathrm{~m}$; C. erythropthalmus was only observed below $500 \mathrm{~m}$. 


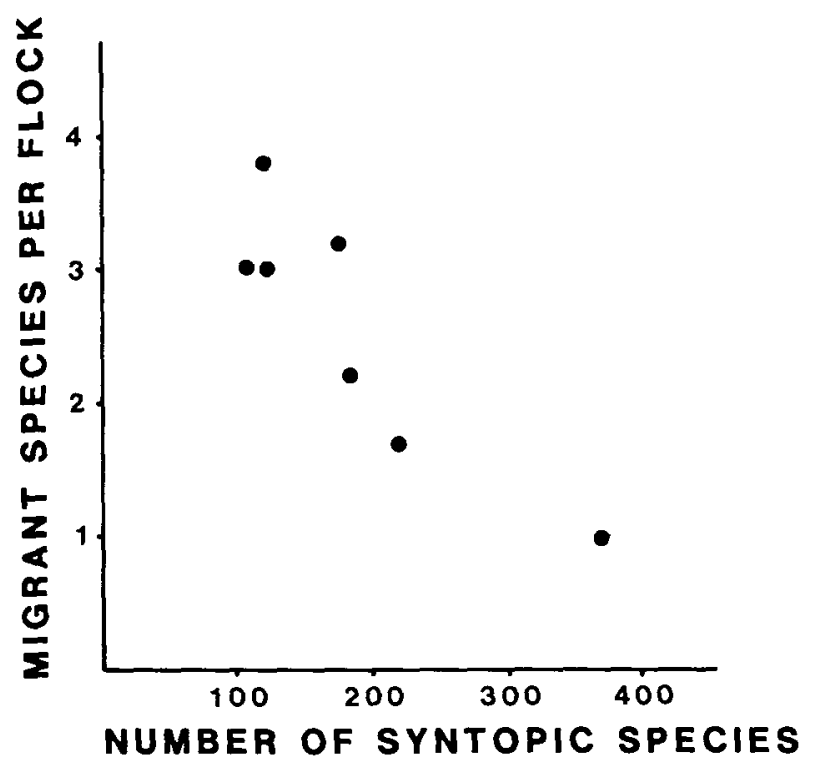

Figure 5. Mean species richness for migrants in mixed-species flocks plotted against richness of resident species at the same sites and elevations. Values for migrants are directly from Figure 4 ; those for residents are from our extensive, unpublished data on forest bird communities at these sites.

\section{Ecuadorean Andes}

Data from the eastern and western slopes of the Ecuadorean Andes (Table 2) showed general similarities to results from the Andes of south-eastern Peru. Migrants were rarely noted in primary forest in the lowlands of both slopes (sites 2 and 7), but were frequently observed in secondary habitats in the Amazonian lowlands (site 1) where Dendroica striata was the most abundant species. Dendroica striata was only observed in more disturbed forest, but Pearson (1980) has also observed it in primary forest in his far more extensive samples. Above $600 \mathrm{~m}$ on both slopes, migrants were found in both primary and secondary habitats. As in Peru, Dendroica fusca and Wilsonia canadensis were the most abundant species in flocks above $600 \mathrm{~m}$ on the eastern slope, but only $D$. fusca was observed on the western slope. Dendroica fusca tolerated highly disturbed habitats, whereas $W$. canadensis was most abundant in primary forest. Contopus borealis was also observed only in primary forest samples. Dendroica cerulea was observed only in primary forest at $1,330 \mathrm{~m}$ on the eastern slope, a similar elevation to its distribution in south-eastern Peru (Robbins et al. 1992b). Empidonax virescens, Setophaga ruticilla and Contopus sordidulus were found only on the western slopes of the Andes; these species were also absent from south-eastern Peru. Surprisingly, Catharus ustulatus, which was abundant in the eastern Andes of Peru, was far more commonly observed on the western slope in Ecuador. Two warblers that primarily winter farther north, Vermivora chrysoptera and Oporornis philadelphia, were both observed at middle elevations on the eastern slope of the Andes. Both Piranga tanagers occurred in disturbed 


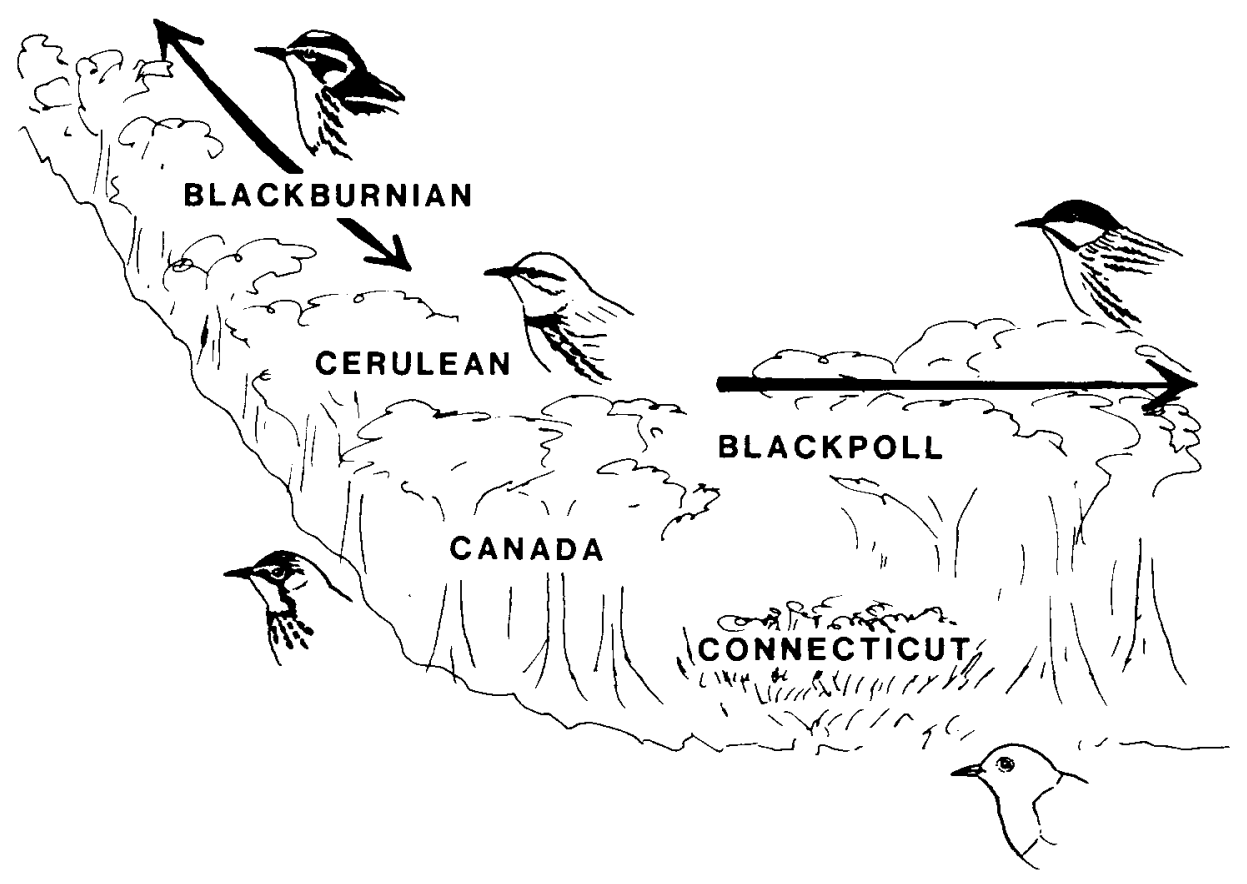

Figure 6. Schematic depiction of ecological and geographic segregation among five species of migrant wood warblers (Parulidae) in the Amazonian and eastern Andean forests (see text).

habitats on the eastern slope, and most migrants on the western slope were found in primary and secondary habitats.

\section{Discussion}

Our results generally show a relatively low abundance and richness of migrants in the vast tropical and subtropical forests of Amazonia and the Andes, which harbour the richest diversity of resident bird species in the world (Terborgh et al. 1990). The inverse pattern holds for the Central American tropics, where northern migrants abound for over half the year (Rappole et al. 1983) and resident tropical bird communities are depauperate by South American standards (Tramer 1974). In this paper, we have shown that this inverse relationship also holds at the local level among habitats within Amazonian lowlands and along an elevational gradient (Figure 2). These results support a general hypothesis that migrant and resident bird communities in the Neotropics do, to some extent, replace one another spatially (Slud 1976, Waide 1980, Leisler 1990). Evolution and radiation of a diverse resident fauna in South America may have inhibited a significant proportion of northern migrants from establishing their primary wintering grounds on that continent. Austral migrants also appear to be concentrated in early successional habitats in south-eastern Peru (Robinson et al. 1988). In turn, the vast numbers of northern breeders crowding into the smaller land area of Central America may in part 
Table 2. Results of censuses of the eastern and western slopes of the Ecuadorean Andes, February 1986

\begin{tabular}{|c|c|c|c|c|c|c|c|c|c|c|c|}
\hline \multirow{4}{*}{$\begin{array}{l}\text { Site number: } \\
\text { Elevation : } \\
\text { Forest type: }\end{array}$} & \multicolumn{6}{|c|}{ Eastern slope } & \multicolumn{5}{|c|}{ Western slope } \\
\hline & 1 & 2 & 3 & 4 & 5 & 6 & 7 & 8 & 9 & 10 & 11 \\
\hline & 380 & 600 & 600 & 1,330 & 1,400 & 1,600 & 225 & 760 & 760 & $1,500^{\mathrm{b}}$ & 1,500 \\
\hline & $2^{\circ}$ & $1^{\circ}$ & $2^{\circ}$ & $1^{\circ}$ & $2^{\circ}$ & $1^{\circ}$ & $1^{\circ}$ & $1^{\circ}$ & $2^{\circ}$ & $1^{\circ}$ & $1^{\circ}$ \\
\hline Myiodynastes luteiventris & 1 & & & & & & & & & & \\
\hline Contopus virens & 1 & & & & 1 & & & & & & \\
\hline C. sordidulus & & & & & & & & & 1 & & \\
\hline C borealis & & & & 3 & & 2 & & & & & \\
\hline Empidonax virescens & & & & & & & 1 & 1 & 2 & 1 & \\
\hline E. alnorim & 1 & & & & & & & & & & \\
\hline Catharus ustulatus & & & & 2 & & & & 5 & 7 & 6 & 1 \\
\hline Vireo flavoviridis & & & & & & & & & $\mathrm{I}$ & & \\
\hline Vermivora chrysoptera & & & & & & $\mathrm{I}$ & & & & & \\
\hline Dendroica fusca & & & & 4 & 4 & 10 & & & 8 & & 6 \\
\hline D. striata & 8 & & 2 & & & & & & & & \\
\hline D. cerulea & & & & 4 & & & & & & & \\
\hline Wilsonia canadensis & & & & 14 & 1 & 4 & & & & & \\
\hline Oporornis philadelphia & & & & & & 1 & & & & & \\
\hline Setophaga ruticilla & & & & & & & & & & & 4 \\
\hline Piranga olivacea & & & & 1 & 2 & & & 1 & & & \\
\hline P. rubra & & & & & 1 & & & 1 & & & \\
\hline Total Migrants & 12 & 0 & 2 & 28 & 9 & 18 & 1 & 6 & 21 & 8 & 11 \\
\hline Total Individuals & 98 & 60 & 58 & 177 & 74 & 104 & 107 & 113 & 87 & 103 & 141 \\
\hline Percentage Migrants & 12.2 & 0.0 & $3 \cdot 4$ & 15.8 & 12.2 & $17 \cdot 3$ & 0.9 & $5 \cdot 3$ & 24.1 & $7 \cdot 3$ & $7 \cdot 3$ \\
\hline
\end{tabular}

a Locations: 1, Río Cocha (medium-tall second growth); 2, 3, between Puyo and Tena; 4, Salto de Coca; 5. Parque Nacional Sangay between Río Bamba and Puyo (second growth); 6, Volcán Reventador (primary cloud-forest), 7, Río Palenque; 8, Tinalandia; 9, Tinalandia (pasture with scattered trees); 10, 11, Hacienda San Vincente near Mindo (primary cloud-forest).

"Mist-net sample.

explain that subcontinent's failure to support as rich a resident community. Alternatively, Central America may contain more migrants for historical reasons - it is closer to the North American breeding grounds of most species. The unpredictable pulses of resources available in early successional habitats, especially those along rivers (Terborgh 1985, Robinson et al. 1988) might also provide migrants with food resources that are not being fully exploited by resident species (Waide 1980). Migrants in the tropical forests of Central Africa (Brosset 1990, Lack 1990, Leisler 1990) and south-east Asia (Wells 1990) are also most abundant in early successional vegetation.

Unfortunately, as with any such historical scenario, the tests that might confirm these competitive dynamics are indirect at best (e.g. Fitzpatrick 1980). Support for the notion that wintering ranges of different species have evolved in concert with one another (Chipley 1980) comes from the conspicuous patterns of geographical replacement among numerous groups of ecologically similar migrants, which includes separation between many species that are sympatric on their breeding grounds. It is therefore possible that the wintering ranges might be adjusted through time with respect to other, resident species as well, or that winter ranges are ancestral. 
A second, confounding pattern of distribution and abundance characterizes those few species that do winter in the South American forests. Most of these species are concentrated toward the western regions of the Amazon basin and the forested slopes of the Andes that form the basin's western rim. This clustering of species appears to counter the above suggestion that species tend to space themselves evenly at a geographical scale. Evolutionary adjustments in distributions that minimize sympatry in winter would tend to produce a more uniform density of migrants than is actually observed (Figure 1). Moreover, the observed clustering of migrants in western Amazonia coincides with an increase in resident species diversity from east to west, exactly opposite to the predictions of the hypothesized inverse effects of residents upon migrants. Migrants may concentrate in the western part of South America because it is closest to the North American breeding grounds (Figure 1), but differences in productivity may also play a role.

The increase in resident species diversity toward western Amazonia characterizes virtually every group and guild of tropical birds (e.g. Haffer 1974 fig. 8.2, Haffer 1978). The same pattern apparently holds generally for mammals (Koopman 1982, Emmons 1984), possibly plants (Gentry 1977, Haffer 1978, Prance 1982), and even native human populations (Meggers 1975). The western Amazon basin supports a substantially more diverse biota than elsewhere. This pattern might reflect higher productivity along the base of the Andes than in the central and eastern Amazonian basin. Indeed, across the Amazon basin, rainfall is much the highest at the base of the Andes, where the foothills cool and condense the vanguard of moisture-laden breezes coming off the humid lowland forests (Simpson and Haffer 1978).

Productivity may also be higher in mid-elevation sites even though resident species richness declines with elevation (Figure 5). In Costa Rica and Venezuela, Janzen $(1973,1976)$ found insect diversity to reach a peak at middle elevations in the mountains, at about 1,200 to $1,500 \mathrm{~m}$. He hypothesized that cooler night temperatures at these elevations promote higher plant productivity, in turn supporting more insect life, by reducing the energetic demands of transpiration. These lower cloud-forest elevations are close to where migrant bird diversity is highest in Peru (Figures 3,4). Resident bird diversity at these elevations is lower than at tropical elevations (Terborgh 1977), for various reasons. A principal cause is that overall diversity of habitats in the montane forests is greatly reduced compared with the lowland Amazon, where river edges, canebrakes, marshes, palm forests, vine tangles, bamboo thickets and highly variable configurations of the forest canopy all contain bird species specializing in these habitats, thereby giving rise to an extremely high regional species richness (Terborgh 1980b, 1985, Remsen and Parker 1983, 1984).

\section{Conservation implications}

The distribution of migrants in Central America differs in several respects from our data from South America. In general, most species of migrant in Central America occupy disturbed, second-growth forests as weli as primary forest (Karr 1976, Waide 1980, Martin 1985, Hutto 1989, Kricher and Davis 1992, Lynch 1992, Petit et al. 1992, Robbins et al. 1992a). Some species that winter in Central 
America, however, are largely confined to forest habitats (Willis 1966, Powell 1980, Terborgh 1980a, 1989, Robbins et al. 1987, Lynch 1989, Rappole et al. 1992) and some species may be intolerant of habitat modifications (Rappole and Morton 1985, Winker et al. 1990, Rappole et al. 1992). Neotropical migrants are far more abundant in primary forest in Central than in South America (Terborgh 1989). Consequently, northern migrants that winter in Amazonia may be less negatively affected by deforestation than those that winter further north (Robinson et al. 1988). Population declines of species that winter primarily in the Amazon basin (e.g. Vireo olivaceus) are perhaps more likely to be attributable to factors associated with the breeding grounds such as forest fragmentation (Wilcove and Robinson 1990, Robinson and Wilcove 1994).

Habitat alteration in Amazonia, however, may still adversely affect some migrants. We know little about how species restricted to successional vegetation along rivers (e.g. Empidonax alnorum, Oporornis agilis) will adapt to human-altered landscapes. Alterations in the hydrology of rivers by damming the Amazon or its tributaries may halt or alter the riparian succession that creates most of the habitats currently used by migrants and many residents (Remsen and Parker 1983, Terborgh 1985, Bolster and Robinson 1990). Similarly, we know little about how deforestation will affect the tree species composition of successional forests. A decline in lauraceous fruits, for example, could adversely affect populations of Tyrannus tyrannus and Myiodynastes luteiventris (Morton 1971, Fitzpatrick 1980, S.K.R. unpubl. data). Some migrants would probably increase as a result of some kinds of human activity, but we know too little to predict which ones. Furthermore, Pearson (1980) has found that migrants make more extensive use of forests in northern Amazonia than we found in southern Amazonia. Stotz et al. (1992) also found that Vireo olivaceus winters in primary forest in Manaus, Brazil.

As argued by Robinson et al. (1988) and Robbins et al. (1992b), the area of greatest conservation concern for migrants in South America appears to be the lower- to middle-elevation forests of the Andes. Most wintering populations of Contopus borealis, Dendroica cerulea and Wilsonia canadensis appear to be restricted to primary forest within this region, which is under severe threat from logging and conversion to coffee, cacao, and coca plantations (Robbins et al. 1992b). Dendroica fusca is also confined to this area, but appears more tolerant of disturbance than the species listed above (Chipley 1976). The abundance of the geographically widespread Catharus ustulatus in the Andes suggests that their populations will also be adversely affected by deforestation of the lower slopes of the Andes.

In summary, our data strongly support the contention of Robbins et al. (1992b) that the lower slopes of the Central Andes should be of the highest conservation priority. Migrants of lowland areas may be more resistant to habitat alteration, but only if they use altered, secondary successional vegetation. Further studies of migrant use of human-altered habitats in Amazonia are necessary before we can evaluate the effects of tropical deforestation on Neotropical migrants.

\section{Acknowledgements}

We are most grateful to Douglas Stotz and David Willard for their extensive and invaluable assistance during many long months in field camps. Their efforts 
helped produce much of the netting and census data reported in this paper. Two anonymous reviewers and T. Schulenberg provided many helpful comments on earlier drafts as did J. D. Brawn and E. J. Heske. We thank the Ministerio de Agricultura, Dirección General Forestal y de Fauna of Peru for their continued cooperation in permitting us to work in their country and their national parks. We gratefully acknowledge the unpublished data and specimen records provided by J. Van Remsen, Jr and Thomas Schulenberg, of Louisiana State University Museum of Natural Science. This research has been funded by the Conover and Ellen Thorne Smith funds of the Field Museum of Natural History, by private grants to J.W.F. from the Bertha LeBus Charitable Trust and Combined International Insurance Corp., by a Guggenheim Fellowship to J.T., and by NSF grants BSR 8508361 to J.W.F., BSR 8514333 to S.K.R., and BSR 8506371-1 to J.T. We are indebted to these institutions for their support. Finally, we would like to express our appreciation of the efforts of Ted Parker, who made it possible for researchers to grasp the magnitude of tropical avian biodiversity.

\section{References}

Bierregaard, R. O., Jr. (1990) Species composition and trophic organization of the understorey bird community in a central Amazonian terra firme forest. Pp.217-234 in A. Gentry, ed. Four neotropical forests. New Haven, Connecticut: Yale University Press.

Bolster, D. C. and Robinson, S. K. (1990) Habitat use and relative abundance of migrant shorebirds in a western Amazonian site. Condor 92: 239-242.

Brosset, A. (1990) A long-term study of the rain forest birds of M'Passa (Gabon). Pp. 259-274 in A. Keast, ed. Biogeography and ecology of forest bird communities. The Hague: SBP Academic Publishing.

Chipley, R. M. (1976) The impact of wintering migrant wood warblers on resident insectivorous passerines in a subtropical Colombian oak wood. Living Bird 15: 119$14 x$.

Chipley, R. M. (1980) Nonbreeding ecology of the Blackburnian Warbler. Pp.309-318 in A. Keast and E. S. Morton, eds. Migrant birds in the Neotropics: ecology, behavior, distribution and conservation. Washington, D.C.: Smithsonian Institution Press.

Davis, S. E. (1989) Migration of the Mississippi Kite Ictinia mississippiensis in Bolivia, with comments on I. plumbea. Bull. Brit. Orn. Club 109: 149-152.

Emmons, L. H. (1984) Geographic variation in densities and diversities of non-flying mammals in Amazonia. Biotropica 16: 210-222.

Finch, D. M. and Stangel, P. W. (1993) Status and management of Neotropical migratory birds. Fort Collins, Colorado: Rocky Mountain Forest and Range Experiment Station.

Fitzpatrick, J. W. (1980) Wintering of North American tyrant flycatchers in the Neotropics. Pp. $67-78$ in A. Keast and E. S. Morton, eds. Migrant birds in the Neotropics: ecology, behavior, distribution, and conservation. Washington, D.C.: Smithsonian Institution Press.

Foster, R. B., Arce, J. B. and Wachter, T. S. (1986) Dispersal and the sequential plant communities in an Amazonian Peru floodplain. Pp.357-370 in A. Estrada and T. H. Fleming, eds. Frugivores and seed dispersal. Dordrecht: Dr W. Junk.

Gentry, A. H. (1977) Endangered plant species and habitats of Ecuador and Amazonian Peru. Pp.136-149 in G. T. Prance and T. S. Elias, eds. Extinction is forever. New York: New York Botanical Garden.

Gilliard, E. T. (1944) Chimney Swifts (?) at Manaus, Brazil. Auk 61: 143-144. 
Greenberg, R. (1992) Forest migrants in non-forest habitats on the Yucatan Peninsula. Pp.273-286 in J. M. Hagan, III and D. W. Johnston, eds. Ecology and conservation of Neotropical migrant landbirds. Washington, D.C.: Smithsonian Institution Press.

Haffer, J. (1974) Avian speciation in tropical South America. Cambridge, Massachusetts: Nuttall Ornithological Club.

Haffer, J. (1978) Distribution of Amazon forest birds. Bonn. Zool. Beitr. 29: 38-78.

Hagan, J. M., III and Johnston, D. W., eds. (1992) Ecology and conservation of Neotropical migrant landbirds. Washington, D.C.: Smithsonian Institution Press.

Hutto, R. L. (1989) The effect of habitat alteration on migratory land birds in a west Mexican tropical deciduous forest: a conservation perspective. Conserv. Biol. 3: 138148.

Janzen, D. (1973) Sweep samples of tropical foliage insects: effects of seasons, vegetation types, elevation, time of day, and insularity. Ecology 54: 687-708.

Janzen, D. (1976) Changes in the arthropod community along an elevational transect in the Venezuelan Andes. Biotropica 8: 193-203.

Karr, J. R. (1976) On the relative abundance of migrants from the north temperate zone in tropical habitats. Wilson Bull. 88: 433-458.

Keast, A. and Morton, E. S., eds. (1980) Migrant birds in the Neotropics: ecology, behavior, distribution, and conservation. Washington, D.C.: Smithsonian Institution Press.

Koopman, K. F. (1982) Biogeography of the bats of South America. Pp.273-302 in M. A. Mares, and H. H. Genoways, eds. Mammalian biology in South America. Pittsburgh, PA: University of Pittsburgh for the Pymatuning Lab. Ecol. (Spec. Publ. Sec. 6).

Kricher, J. C. and Davis, W. E., Jr. (1992) Patterns of avian species richness in disturbed and undisturbed habitats in Belize. Pp.240-246 in J. M. Hagan, III and D. W. Johnston, eds. Ecology and conservation of Neotropical migrant landbirds. Washington, D.C.: Smithsonian Institution Press.

Lack, P. C. (1990) Palaearctic-African systems. Pp.345-346 in A. Keast, ed. Biogeography and ecology of forest bird communities. The Hague: SBP Academic Publishing.

Leisler, B. (1990) Habitat selection and utilization of wintering migrants. Pp.156-174 in E. Gwinner, ed. Bird migration physiology and ecophysiology. Berlin: Springer.

Lincoln, F. C. (1944) Chimney Swift's winter home discovered. Auk 61: 604-6o9.

Lynch, J. F. (1989) Distribution of overwintering nearctic migrants in the Yucatan Peninsula. I. General patterns of occurrence. Condor 91: 515-544.

Lynch, J. F. (1992) Distribution of overwintering nearctic migrants in the Yucatan Peninsula. II. Use of native and human-modified vegetation. Pp.178-195 in J. M. Hagan, III and D. W. Johnston, eds. Ecology and conservation of Neotropical migrant landbirds. Washington, D.C.: Smithsonian Institution Press.

Martin, T. E. (1985) Selection of second-growth woodlands by frugivorous migrating birds in Panama: an effect of fruit size and density? J. Trop. Ecol. 1: 157-170.

Meggers, B. J. (1975) Application of the biological model of diversification to cultural distributions in tropical lowland South America. Biotropica 7: 141-161.

Morton, E. S. (1971) Food and migration habits of the Eastern Kingbird in Panama. Auk 88: $925-926$.

Munn, C. A. (1985) Permanent canopy and understory flocks in Amazonia: species composition and population density. Pp.683-712 in P. A. Buckley, M. S. Foster, E. S. Morton, R. S. Ridgely and F. G. Buckley, eds. Neotropical ornithology. Washington, D.C.: American Ornithologists' Union (Orn. Monogr. 36).

Munn, C. A. and Terborgh, J. W. (1979) Multispecies territoriality in Neotropical foraging flocks. Condor 81: 338-347.

Parker, T. A. (1982) Some observations of unusual rainforest and marsh birds in south-eastern Peru. Wilson Bull. 94: 477-493.

Parker, T. A., Parker, S. A. and Plenge, M. A. (1982) An annotated checklist of Peruvian birds. Vermillion, South Dakota: Buteo Books. 
Pearson, D. L. (1980) Bird migration in Amazonian Ecuador, Peru, and Bolivia. Pp.273284 in A. Keast and E. S. Morton, eds. Migrant birds in the Neotropics: ecology, behavior, distribution, and conservation. Washington, D.C.: Smithsonian Institution Press.

Petit, D. R., Petit, L. J. and Smith, K. G. (1992) Habitat associations of migratory birds overwintering in Belize, Central America. Pp.247-256 in J. M. Hagan, III and D. W. Johnston, eds. Ecology and conservation of Neotropical migrant landbirds. Washington, D.C.: Smithsonian Institution Press.

Powell, G. V. N. (1980) Migrant participation in Neotropical mixed species flocks. Pp. 477-484 in A. Keast and E. S. Morton, eds. Migrant birds in the Neotropics: ecology, behavior, distribution, and conservation. Washington, D.C.: Smithsonian Institution Press.

Powell, G. V. N. (1985) Sociobiology and adaptive significance of interspecific foraging flocks in the Neotropics. Pp.713-732 in P. A. Buckley, M. S. Foster, E. S. Morton, R. S. Ridgely and F. G. Buckley, eds. Neotropical ornithology. Washington, D.C.: American Ornithologists' Union (Orn. Monogr. 36).

Prance, G. T., ed. (1982) Biological diversification in the tropics. New York: Columbia University Press.

Rappole, J. H. and Morton, E. S. (1985) Effects of habitat alteration on a tropical avian forest community. Pp.1013-1021 in P. A. Buckley, M. S. Foster, E. S. Morton, R. S. Ridgely and F. G. Buckley, eds. Neotropical ornithology. Washington, D.C.: American Ornithologists' Union (Orn. Monogr. 36).

Rappole, J. H., Morton, E. S. and Ramos, M. A. (1992) Density, philopatry, and population estimates for songbird migrants wintering in Veracruz. Pp.337-344 in J. M. Hagan, III and D. W. Johnston, eds. Ecology and conserzation of Neotropical migrants landbirds. Washington, D.C.: Smithsonian Institution Press.

Rappole, J. H., Morton, E. S., Lovejoy, T. E., III and Rous, J. (1983) Nearctic avian migrants in the Neotropics. Washington, D.C.: U.S. Fish and Wildlife Service.

Remsen, J. V. and Parker, T. A. (1983) The contribution of river-created habitats to bird species richness in Amazonia. Biotropica 15: 223-231.

Remsen, J. V., Jr., and Parker, T. A., III (1984) Arboreal dead-leaf-searching birds of the neotropics. Condor 86: 36-41.

Robbins, C. S., Dowell, B. A., Dawson, D. K., Colon, J., Espinoza, F., Rodriguez, J., Sutton, R. and Vargas, T. (1987) Comparison of Neotropical winter bird populations in isolated patches versus extensive forest. Acta Oecologia: Oecologia Gen. 8: 285-292.

Robbins, C. S., Dowell, B. A., Dawson, D. K., Colon, J. A., Estrada, R., Sutton, A., Sutton, R. and Weyer, D. (1992a) Comparison of neotropical migrant landbird populations wintering in tropical forest, isolated forest fragments, and agricultural habitats. Pp.207-220 in J. M. Hagan, III and D. W. Johnston, eds. Ecology and conseriation of Neotropical migrant landbirds. Washington, D.C.: Smithsonian Institution Press.

Robbins, C. S., Fitzpatrick, J. W. and Hamel, P. B. (1992b) A warbler in trouble: Dendroica cerulea. Pp.549-562 in J. M. Hagan, III and D. W. Johnston, eds. Ecology and conservation of Neotropical migrant landbirds. Washington, D.C.: Smithsonian Institution Press.

Robinson, S. K. and Terborgh, J. (1990) Bird communities of the Cocha Cashu Biological Station in Amazonian Peru. Pp.199-216 in A. Gentry, ed. Four neotropical forests. New Haven, Connecticut: Yale University Press.

Robinson, S. K. and Wilcove, D. S. (1994) Forest fragmentation in the temperate zone and its effects on migratory songbirds. Bird Conserv. Internatn. 4: 233-249.

Robinson, S. K., Terborgh, J. and Munn, C. A. (1990) Lowland tropical forest bird communities of a site in western Amazonia. Pp.229-258 in A. Keast, ed. Biogeography and ecology of forest bird communities. The Hague: SBP Academic Publishing.

Robinson, S. K., Terborgh, J. and Fitzpatrick, J. W. (1988) Habitat selection and relative abundance of migrants in southeastern Peru. Proc. XIX Internatn. Orn. Congr.: 22982311. 
Salo, J., Kalliola, R., Häkkinen, I., Mäkinen, Y., Niemelä, P., Puhakka, M. and Coley, P. D. (1986) River dynamics and the diversity of Amazon lowland forest. Nature 322: 254-258.

Simpson, B. B. and Haffer, J. (1978) Speciation patterns in the Amazonian forest biota. Annu. Rev. Ecol. Syst. 9: 497-518.

Slud, P. (1976) Geographic and climatic relationships of avifaunas with special reference to comparative distribution in the neotropics. Smithsonian Contrib. Zool. 212: 1-149.

Stotz, D. F., Bierregaard, R. O., Cohn-Haft, M., Petermann, P., Smith, J., Whittaker, A. and Wilson, S. V. (1992) The status of North American migrants in central Amazonian Brazil. Condor 94: 608-621.

Terborgh, J. (1989) Where have all the birds gone? Princeton: Princeton University Press.

Terborgh, J. and Petren, K. (1991) Development of habitat structure through succession in an Amazonian floodplain forest. Pp.28-46 in S. S. Bell, E. D. McCoy and H. R. Mushinsky, eds. Habitat structure: the physical arrangement of objects in space. London: Chapman and Hall.

Terborgh, J., Robinson, S. K., Parker, T. A., III, Munn, C. A. and Pierpont, N. (1990) Structure and organization of an Amazonian bird community. Ecol. Monogr. 60: 213238.

Terborgh, J. W. (1977) Bird species diversity on an Andean elevational gradient. Ecology 58: 1007-1019.

Terborgh, J. W. (1980a) The conservation status of Neotropical migrants: present and future. Pp.21-30 in A. Keast and E. S. Morton, eds. Migrant birds in the Neotropics: ecology, behavior, distribution, and conservation. Washington, D.C.: Smithsonian Institution Press.

Terborgh, J. W. (1980b) Causes of tropical species diversity. Proc. XVII Internatn. Orn. Congr.: 955-961.

Terborgh, J. W. (1985) Habitat selection in Amazonian birds. Pp.311-338 in M. L. Cody, ed. Habitat selection in birds. Orlando: Academic Press.

Terborgh, J. W., Fitzpatrick, J. W. and Emmons, L. (1984) Annotated checklist of bird and mammal species of Cocha Cashu Biological Station, Manu National Park, Peru. Fieldiana Zool. 21: 1-29.

Tramer, E. J. (1974) On latitudinal gradients in avian diversity. Condor 76: 123-130.

Waide, R. B. (1980) Resource partitioning between migrant and resident birds: the use of irregular resources. Pp. 337-352 in A. Keast and E. S. Morton, eds. Migrant birds in the Neotropics: ecology, behavior, distribution, and conservation. Washington, D.C.: Smithsonian Institution Press.

Wells, D. R. (1990) Migratory birds and tropical forest in the Sunda region. Pp.357-369 in A. Keast, ed. Biogeography and ecology of forest bird communities. The Hague: SBP Academic Publishing.

Wilcove, D. S. and Robinson, S. K. (1990) The impact of forest fragmentation on bird communities in eastern North America. Pp.319-331 in A. Keast, ed. Biogeography and ecology of forest bird communities. The Hague: SBP Academic Publishing.

Willis, E. O. (1966) The role of migrant birds at swarms of army ants. Living Bird 5: 187231.

Winker, K., Rappole, J. and Ramos, M. A. (1990) Population dynamics of the Wood Thrush in southern Veracruz, Mexico. Condor 92: 444-460.

\section{SCOTT K. ROBINSON}

Illinois Natural History Survey, 607 E. Peabody Dr., Champaign, Illinois 61820, U.S.A.

JOHN W. FITZPATRICK

Archbold Biological Station, P.O. Box 2057, Lake Placid, Florida 33852, U.S.A. 


\section{JOHN TERBORGH}

Center for Tropical Conservation, Duke University, 3705 Erwin Road, Durham, North Carolina 27705 , U.S.A.

Appendix 1. North American landbird species with substantial winter populations in Amazonia and adjacent eastern Andes"

\begin{tabular}{|c|c|c|c|c|}
\hline & $\begin{array}{l}\text { Foraging } \\
\text { guild }^{b}\end{array}$ & Habitat & $\begin{array}{c}\text { Regional } \\
\text { distribution }^{\mathrm{d}}\end{array}$ & Elevation (m) \\
\hline Buteo platypterus & $\mathrm{p}$ & $\mathrm{f}$ & $1-4$ & $300-3,000$ \\
\hline Coccyzus erythropthalmus & $\mathrm{f}$ & $\mathrm{f}$ & $1-4$ & $0-2,000$ \\
\hline Coccyzus anericanus & $\mathrm{g}$ & $\mathrm{f}$ & $1-5,7$ & $0-2,000$ \\
\hline Chordeiles minor & a & $\mathrm{a}$ & $3-7$ & $0-1,800$ \\
\hline Chaetura pelagica & $\mathrm{a}$ & a & $3,5 ?$ & $o-?$ \\
\hline Tyranmus tyrammus & $\mathrm{a}, \mathrm{fr}$ & $\mathrm{e}$ & 3,4 & $0-500$ \\
\hline Myiodynastes luteizentris & $\mathrm{g}, \mathrm{fr}$ & f, e & 2,4 & $250-1,000$ \\
\hline Contopus borealis & a & $\mathrm{f}$, e & 1,2 & $350-2,000$ \\
\hline Contopus irirens & a & $f, e$ & $1-4$ & $200-1,700$ \\
\hline Contopus sordidulus & a & $\mathrm{f}, \mathrm{e}$ & 1,2 & $900-2,800$ \\
\hline Empidonax alnornm & $g$ & $\mathrm{e}$ & 3,4 & $200-500$ \\
\hline Progne subis & a & a & $3-7 ?$ & $0-300$ \\
\hline Riparia riparia & $\mathrm{a}$ & $\mathrm{a}$ & $3,4,6$ & $0-500$ \\
\hline Hirundo rustica & a & $\mathrm{a}$ & $3-7$ & $0-500$ \\
\hline Catharus ustulatus & $\mathrm{g}, \mathrm{fr}$ & $\mathrm{f}, \mathrm{e}$ & $1-4$ & $200-2,150$ \\
\hline Catharus minimus & $\mathrm{g}, \mathrm{fr}$ & $\mathrm{f}, \mathrm{e}$ & $1,3,5$ & $0-3,000$ \\
\hline Catharus fuscescens & $\mathrm{g}, \mathrm{fr}$ & $\mathrm{f}, \mathrm{e}$ & $5-7$ & $0-300$ \\
\hline Vireo olizaceus & $\mathrm{g}, \mathrm{fr}$ & $\mathrm{f}, \mathrm{e}$ & $1-6$ & $200-2,000$ \\
\hline Vireo flavowiridis & $\mathrm{g}, \mathrm{fr}$ & $\mathrm{f}, \mathrm{e}$ & $1-4$ & $200-1,200$ \\
\hline Vireo altiloquus & $g, f r$ & $\mathrm{f}, \mathrm{e}$ & 3 & $0-?$ \\
\hline Dendroica petechia & $g$ & $\mathrm{~s}, \mathrm{~m}$ & 3,5 & $0-300$ \\
\hline Dendroica cerulea & $\mathrm{g}$ & $\mathrm{f}$ & 1,2 & $750-1,300$ \\
\hline Dendroica fusea & $g$ & $\mathrm{f}$ & 1,2 & $1,000-3,000$ \\
\hline Dendroica striata & $\mathrm{g}$ & f & $3-5$ & $0-350$ \\
\hline Oporomis agilis & $g$ & $e, s$ & $3-6$ & $0-350$ \\
\hline Wilsonia canadensis & $\mathrm{g}$ & $\mathrm{f}$ & 1,2 & $600-2,500$ \\
\hline Piranga rubra & $\mathrm{g}, \mathrm{fr}$ & $\mathrm{f}$ & $1-4$ & $200-2,200$ \\
\hline Piranga olizacea & $\mathrm{g}, \mathrm{fr}$ & $\mathrm{f}$ & $1-4$ & $200-1,800$ \\
\hline Phencticus ludonicinmus & $\mathrm{g}, \mathrm{fr}$ & $\mathrm{f}$ & 1,2 & $1,000-2,800$ \\
\hline
\end{tabular}

a The following species, which winter in Amazonia in small numbers, are excluded from the list because their principal winter ranges lie elsewhere: Tyrannus dominicensis, Empidonax traillii, Petrochelidon pyrrhonota, Vermiora chrysoptera, Seimns noveboracensis, Oporornis philadelphia, Setophaga ruticilla.

${ }^{\mathrm{b}} \mathrm{p}$, vertebrate predator; $\mathrm{g}$, foliage gleaner; fr, frugivore; $a$, aerial insectivore.

' $f$, primary forest; $e$, forest edge, openings; a, aerial; $s$, savanna; $m$, marshes.

d 1 , eastern Andean slopes north of Rio Marañon; 2, eastern Andean slopes south of Rio Marañon; 3, lowland forest north of Amazon, west of Rio Negro; 4, lowland forest south of Amazon, west of Rio Purus; 5, lowland forest north of Amazon, east of Rio Negro; 6, lowland forest south of Amazon, between Rios Purus and Tapajoz; 7, lowland forest south of Amazon, east of Rio Tapajoz. "Winter range of Chaetura pelagica is still poorly known; Amazonian populations are assumed on basis of Gilliard (1944) and Lincoln (1944); large populations are known to occur in Peru west of Andes (Parker $\varepsilon$ t al. 1982). 